\title{
ANALISIS PARADIGMA MAHASISWA TERHADAP KEWIRAUSAHAAN \\ (Studi Pada Mahasiswa Prodi Manajemen Universitas Pamulang Tahun Ajaran 2017/2018)
}

\author{
KUSWORO' $^{1)}$, IVAN PUTRANTO' ${ }^{2)}$ \\ ${ }^{1}$ Dosen Pendidikan Ekonomi, Universitas Pamulang \\ ${ }^{2}$ Dosen Manajemen, Universitas Pamulang \\ dosen01674@unpam.ac.id ${ }^{1)}$, ivanputranto21@gmail.com ${ }^{2}$
}

\begin{abstract}
ABSTRAK
Penelitian ini bertujuan untuk mengalisis gambaran umum tentang mahasiswa Prodi Manajemen dan mengalisis bagaimana paradigma mahasiswa terhadap kewirausahaan. Jenis penelitian ini adalah metode kualitatif. Lokasi penelitian dilakukan di Program studi Manajemen Universitas Pamulang. Penetapan informan sebagai sumber data yang dipilih menggunakan teknik purposive sampling. Pengumpulan data menggunakan teknik observasi, wawancara dan dokumentasi. Keabsahan data diperoleh melalui credibility, transferability, dependability, dan confirmatory. Analisis data kualitatif: reduksi data, paparan data, dan penarikan kesimpulan. Hasil penelitian menunjukkan bahwa mahasiswa program studi manajemen tahun ajaran 2017/2018 yang merupakan wirausahawan yaitu reguler A sejumlah 19 mahasiswa, reguler B sejumlah 34 mahasiswa, dan reguler $\mathrm{C}$ sejumlah 55 mahasiswa. Berbagai bidang usaha yang dijalankan mahasiswa antara lain dibidang jasa, perdagangan, dan kuliner. Usia usaha mahasiswa dimulai dari 0 hingga 5 tahun. Sumber modal usaha yang diperoleh mahasiswa berasal dari modal sendiri dan pinjaman. Paradigma mahasiswa tentang kewirausahaan difokuskan pada karakteristik, inovasi dalam wirausaha dan memiliki modal usaha. Paradigma mahasiswa mengenai karakteristik wirausaha seperti pantang menyerah jika terjadi kegagalan, kepemimpinan yang baik, berani mengambil resiko, bisa mengatasi permasalahan yang dihadapi dengan cepat atau responsif terhadap perubahan, berorientasi pada masa depan, jujur, tekun, dan disiplin. Paradigma mahasiswa tentang inovasi yaitu peningkatan layanan dan pembaharuan produk, antisipasi perubahan. Inovasi merupakan hal yang sangat penting dalam sebuah usaha. Pembaharuan akan strategi, produk dan layanan akan membantu seorang wirausaha dalam mempertahankan usaha yang dijalankan. Paradigma mahasiswa terkait dengan modal yaitu berupa uang yang digunakan untuk menjalankan aktivitas usaha. Modal merupakan sesuatu yang sangat penting untuk memulai sebuah usaha. Selain modal berupa uang, hal yang tidak kalah penting adalah modal berupa ide kreatif.
\end{abstract}

Kata Kunci : Paradigma, Kewirausahaan, Mahasiswa 


\section{PENDAHULUAN}

Perkembangan

arus

globalisasi merupakan suatu proses kehidupan yang menghapus batas geografi, sosial, ekonomi dan budaya. Globalisasi menghubungkan bangsa-bangsa di dunia menuju ke sebuah tatanan kehidupan baru. Hal ini tentu memengaruhi berbagai bidang kehidupan bangsa dan negara. Pesatnya arus globalisasi yang masuk ke berbagai bidang kehidupan negara merupakan hal yang sulit untuk dihindari di zaman yang modern ini. Perkembangan globalisasi akan memengaruhi dan berdampak diberbagai bidang kehidupan baik positif maupun negatif. Pengaruh globalisasi ini dapat dirasakan dalam berbagai bidang kehidupan. Tidak hanya bidang ekonomi, industri, namun perubahan juga terlihat jelas dalam bidang pendidikan.

Bebarapa hal yang harus dipersiapkan bangsa Indonesia untuk menghadapi globalisasi adalah dengan meningkatkan kualitas Sumber Daya Manusia (SDM) yang dapat dilihat berdasarkan Indeks Pembangunan Manusia/ IPM (Human Development Indeks). Berdasarkan data Human Development Report Tahun 2015 bahwa negara Indonesia terdapat pada peringkat 113 dari total 188 negara yang ada di dunia, termasuk kedalam kategori medium HDI. Hal ini tentunya menjadi permasalahan yang perlu segera diatasi untuk menghadapi persaingan bebas.

Untuk

mengatasi

permasalahan tersebut pendidikan memiliki peran yang sangat penting. Tuntutan jenjang pendidikan dan peningkatan kualitas SDM sudah tidak bisa dihindari lagi. Selain berdampak pada pendidikan itu sendiri, pengaruh globalisasi juga akan berdampak pada berbagai sektor, salah satunya adalah sektor ekonomi. Perkembangan ekonomi dipengaruhi oleh berbagai faktor, salah satunya adalah sumber daya manusia (SDM). Perkembangan ekonomi harus didukung oleh semua pihak agar kondisi perekonomian yang sudah berkembang bisa menjadi lebih baik lagi.

Seiring dengan hal tersebut, perkembangan dunia kerja juga mengalami perkembangan yang sangat pesat. Perkembangan ini memiliki konsekuensi pada ketatnya persaingan pada dunia usaha dan industri. Sementara pencari pekerjaan dari tahun ke tahun semakin banyak. Selain itu juga tingkat kesadaran masyarakat akan pentingnya pendidikan tinggi (mahasiswa) dengan harapan akan mendapatkan pekerjaan yang lebih baik. Akan tetapi, kesempatan kerja (lapangan kerja) yang dibutuhkan tidak sebanding dengan pencari kerja. Hal ini akan berdampak pada tingkat pengangguran (jobless)

Berdasarkan data dari Badan

Pusat Statistik Provinsi Banten 
menunjukkan bahwa tingkat pengangguran terbuka Kota Tangerang Selatan mengalami kenaikan 4,56\% di tahun 2013 dan $6,29 \%$ di tahun 2014. Hal ini sudah cukup menjadi dasar bagi pemerintah Kota Tangerang Selatan untuk memberikan perhatian lebih, khususnya bagi masyarakat agar menjadikan wirausaha sebagai alternatif pilihan sumber penghasilan.

Untuk mengantisipasi hal tersebut, sudah menjadi tanggung kita semua agar tingkat pengangguran tidak semakin bertambah. Untuk itu perlu alternatif lain dengan menumbuhkan jiwa berwirausahaan pada mahasiswa dengan harapan dapat membuka lapangan pekerjaan dan menjadi solusi mengatasi tingginya tingkat pengangguran.

Kewirausahaan mempunyai dampak yang sangat penting terhadap perekonomian suatu negara. Semakin banyak usaha-usaha kecil menengah dalam suatu negara semakin mempercepat pertumbuhan ekonomi, begitu juga sebaliknya. Sehubungan dengan hal tersebut maka perlu menumbuhkan Usaha Kecil Mengeah (UKM).

Berdasarkan data Jumlah Pelaku UKM Kota Tangerang Selatan dari Dinas Koperasi dan UKM Kota Tangerang Selatan dapat diketahui bahwa pelaku UMKM sampai pada tahun 2017 untuk kategori Mikro berjumlah 15.102.
Pelaku UMKM kategori Kecil berjumlah 6.728, sedangkan pelaku UMKM kategori Menengah berjumlah 4170. Pelaku UMKM seperti inilah yang perlu dikembangkan dari segi kualitas dan kuantitasnya, karena perannya sangat penting terhadap perekonomian.

Untuk menumbuhkan jiwa wirausaha, hal yang perlu mendapat perhatian adalah merubah pola pikir dari mencari pekerja menjadi pembuka lapangan kerja. Universitas Pamulang adalah universitas yag ada di kota Tangerang Selatan. Secara khusus Universitas Pamulang bertujuan mewujudkan pendidikan yang murah dan terjangkau untuk seluruh lapisan masyarakat. Pendidikan yang murah tentu tanpa melupakan kualitas dari pendidikan. Seiring dengan pendidikan yang dilakukan oleh masyarakat Indonesia maka secara otomatis akan meningkatkan kualitas SDM serta daya jual masyarakat Indonesia.

Penelitian ini lebih difokuskan pada prodi manajemen yang masih relevan dengan bidang kewirausahaan. Jumlah mahasiswa Prodi Manajemen tidak kurang dari 14.501 mahasiswa merupakan potensi yang besar untuk mengembangkan dan menumbuhkan minat wirausaha perguruan tinggi. Melihat fenomena yang ada bahwasanya mahasiswa lebih tertarik untuk menjadi pegawai dibanding menjadi wirausaha, maka peneliti tertarik untuk menganalisa 
paradigma mahasiswa terhadap kewirausahaan.

\section{HASIL DAN PEMBAHASAN \\ Hasil Penelitian \\ Gambaran Umum Responden}

Responden dalam penelitian ini adalah mahasiswa Program Studi Manajemen Universitas Pamulang tahun ajaran 2017/2018. Berdasarkan hasil observasi dan dukumentasi yang telah dilakukan diketahui jumlah mahasiswa Universitas Pamulang tahun ajaran 2017/2018 terbagi menjadi 3 bagian yaitu Reguler A (Pagi) sebanyak 4.509 mahasiswa, Reguler B (Malam) sebanyak 5.820 mahasiswa, dan Reguler C (Eksekutif) sebanyak 9.162 mahasiswa. Jumlah mahasiswa aktif terdiri dari mahasiswa yang dinyatakan aktif dalam perkuliahan dan sedang menyelesaikan tugas akhir (skripsi). Jumlah mahasiswa non aktif terdiri dari mahasiswa yang dinyatakan non aktif, cuti, dan tidak ada keterangan.

Jumlah mahasiswa Prodi Manajemen Universitas Pamulang reguler A sebanyak 1.403 mahasiswa, jumlah mahasiswa program studi manajemen reguler B sebanyak 1.222 mahasiswa dan jumlah mahasiswa program studi manajemen reguler $\mathrm{C}$ sebanyak 1.911 mahasiswa. Jumlah tersebut merupakan potensi yang besar untuk menghasilkan mahasiswa yang memiliki kemampuan berpikir ekonomi kreatif melalui kewirausahaan. Mahasiswa program studi manajemen tahun ajaran 2017/2018 yang merupakan wirausahawan reguler A sejumlah 19 mahasiswa, reguler $\mathrm{B}$ sejumlah 34 mahasiswa, dan reguler $\mathrm{C}$ sejumlah 55 mahasiswa. Bidang usaha yang dilakukan oleh mahasiswa diantaranya tergolong dalam usaha kuliner sebanyak 21 mahasiswa, bidang jasa sebanyak 34 mahasiswa, dan bidang usaha perdagangan sebanyak 53 mahasiswa. Sumber permodalan mahasiswa mayoritas berasal dari sumber mandiri yaitu sebanyak 94 mahasiswa dan sebagiannya memperoleh modal dari pinjaman. Lama usaha yang dilakukan oleh mahasiswa mulai rentang 0 sampai dengan 5 tahun. Mahasiswa UNPAM secara umum belum memiliki minat terhadap kewirausahaan. Hal ini dapat dilihat melalui barometer kurangnya antusias mahasiswa menyikapi kewirausahaan yang diadakan oleh perguruan tingggi baik melalui seminar kewirausahaan maupun lomba proposal bisnis kewirausahaan.

Kewirausahaan yaitu sikap yang dimiliki oleh seorang wirausaha serta kemampuan untuk berkreasi dalam menciptakan sesuatu yang memiliki inovasi dan bernilai untuk memenuhi kebutuhannya dan orang lain. Berdasarkan hasil penelitian dan wawancara yang telah dilakukan kepada mahasiswa Universitas Pamulang tahun ajaran 2017/2018 
diketahui mahasiswa yang memiliki usaha di samping menjadi seorang mahasiswa masih relatif sedikit jika dibandingkan dengan jumlah mahasiswa Universitas Pamulang. Hal ini dikarenakan hampir sebagian besar mahasiswa Universitas Pamulang adalah pekerja. Kematangan wirausaha dalam hal ini berkaitan dengan pengalaman dalam melakukan usaha dapat dilihat dari usia lama berwirausaha. Sesorang yang sudah matang dalam melakukan usaha memiliki pengamatan yang berbeda dalam melihat peluang dan hambatan dalam berwirausaha. Lama usia usaha akan memberikan pengetahuan dan pengalaman yang dimiliki oleh seorang wirausaha dalam menjalankan usahanya. Oleh karena itu, lama usaha jukan menentukan kstabilan dalam menjalankan usaha baik dari segi modalitas maupun keuntungan.

\section{Paradigma Mahasiswa Terhadap Kewirausahaan}

Kewirausahaan merupakan suatu nilai yang dibentuk dalam sebuah perilaku untuk dijadikan sumber daya, kiat, serta proses, untuk mencapai tujuan berupa hasil bisnis. Kewirausahaan juga sebuah nilai yang dibutuhkan oleh seorang wirausaha untuk memulai sebuah usaha dan mengembangkan usaha untuk menjadi lebih besar. Kewirausahaan juga dapat didefinisikan suatu proses untuk melakukan sesuatu yang baru dan berbeda untuk agar dapat bermanfaat dalam memberikan nilai lebih untuk masyarakat. Berdasarkan hasil wawancara dan penelitian diketahui paradigma kewirausahaan mahasiswa program studi manajemen Universitas Pamulang.

\section{Karakteristik Kewirausahaan}

Seorang wirausahawan haruslah seorang yang mampu melihat peluang kedepan. Pandangan kedepan dalam memakasimalkan peluang dengan berfikir penuh perhitungan mencari pilihan dari berbagai alternatif masalah dan pemecahnnya. Selain itu, untuk menjadi seorang wirausahawan harus memiliki karakter. Hal ini dapat diketahui dari pemaparan informan 1:

"Jika ingin menjadi wirausaha yang berhasil kita harus bangkit dari kegagalan, gagal coba lagi, gagal coba lagi",

Berdasarkan pernyataan tersebut seorang wirausaha harus memiliki karakter pentang menyerah. Pantang menyerah merupakan salah satu karakteristik yang harus dimiliki oleh seorang wirausahaan, meskipun rintangan yang dihadapi penuh pengorbanan demi mencapai tujuan yang diharapkan yaitu mendapatkan keuntungan.

Hal ini senada dengan apa yang dikatakan oleh informan 2, salah seorang mahasiswa program studi manajemen: 
"Resiko kegagalan pasti ada, yang paling penting bagaimana kita bisa bangkit dari kegagalan tersebut"

Sikap yang penuh semangat dan berjuang keras (pantang menyerah) sehingga menimbulkan dampak yang baik. Seorang yang berwirausaha harus memiliki motivasi serta sikap yang tidak mudah menyerah. Hal ini karena dalam aktivitas usaha tentunya memiliki risiko yang besar dalam kegagalan. Saat awal pendirian terdapat untung dan rugi yang tidak diketahui.

Tidak jauh berbeda denga apa yang dikatakan oleh informan 3 terkait dengan karakteristik dalam berwirausaha:

"Kita harus bisa bangkit dari setiap kegagalan, wirausaha yang berhasil adalah wirausaha yang gigih atau pantang menyerah"

Berdasarkan pernyataan dari informan tersebut diketahui bahwa syarat seorang wirausaha yang berhasil adalah gigih atau pantang menyerah. Hal ini dikarenakan apabila seorang wirausaha tidak memiliki karakter seperti itu maka bagaimana mungkin usaha yang dilakukan akan berhasil. Sedangkan informan 4 mengatakan:

"Tidak ada usaha yang langsung berhasil, semua pasti perah mengalami tahap kegagalan"

Berwirausaha juga belum tentu menjamin kesuksesan. Sebelum merasakan kesuksesan, mayoritas wirausahawan pasti pernah mengalami kegagalan. Hanya wirausaha yang pantang menyerah yang akan berhasil melewati tahap kegagalan.

Berkaitan dengan karakteristik informan 5 menyikapi dari segi kepemimpinan:

"Tumbuh kembangnya sebuah usaha tergantung bagaimana seorang wirausaha memiliki sifat kemepimpinan untuk memimpin bawahan atau karyawannya"

Berdasarkan hasil wawancara tersebut maka peran pemimpin sangat besar dalam memberikan pengarahan terhadap karyawan atau dalam menyampaikan ide atau gagasan kepada karyawan sehingga apa yang menjadi pemikiran pempinan bisa tersampaikan dengan baik. Kemampuan seorang wirausaha dapat dilihat dari bagaimana seorang wirausaha mampu untuk menelola usahanya dengan baik. Keterampilan dalam mengelola suatu usaha perlu dimiliki oleh seorang wirausaha diantaranya dalam merencanakan, mengorganisasikan, menggerakan karyawan serta mengevaluasi hasil usaha yang dijalankannya.

Hal senada juga diungkapakan oleh informan 6 terkait dengan karakteristik berupa kepemimpinan:

"Sebuah usaha akan berjalan dengan baik jika pemimpin mampu memimpin karyawannya, mampu mengarahkan karyawannya, mampu menggerakkan karyawannya ke arah yang lebih baik lagi” 
Pendapat di atas menjelaskan bahwa seorang pemimpin yang baik akan bisa membawa usaha melalui karyawannya ke arah yang lebih baik. Jika pemimpin tidak bisa melakukan hal itu, maka karakteristik berupa kepemimpinan yang baik tidak terpenuhi dalam sebuah usaha.

"Jika kita memulai usaha dari kecil kemudian kita tekuni bukan tidak mungkin akan menjadi besar dan memiliki karyawan. Di sinilah kita sebagai pemimpin memiliki peran yang sangat penting terhadap kelangsungan usaha" pendapatan yang dikemukakan oleh informan 7.

"Salah satu karakteristik dalam kewirausahaan adalah kepemimpinan yang baik. Pemimpin yang baik mampu melakukan kerja sama untuk mencapai tujuan yang diinginkan" ujar informan 8.

Keberhasilan dan kegagalan suatu usaha terletak peran seorang pemimpin dalam mengelola usaha. Pemimpin perusahaan merupakan pemain utama dan sumber yang langka di dalam setiap perusahaan. Wirausahawan yang berhasil merupakan pemimpin yang berhasil, pemimpin yang dapat menguasai dan mengembangkan diri sendiri, dan juga mampu menguasai serta mengarahkan dan mengembangkan para karyawannya

Pendapat yang sedikit berbeda dikemukakan oleh informan 9 mengenai karakteristik:
"Kalau menurutku salah satu karakteristik yang perlu dimiliki oleh seorang wirausaha adalah berani mengambil resiko. Apabila hanya bermain di zona nyaman maka akan sulit berkembang"

Keberanian

menghadapi risiko yang didukung komitmen yang kuat, mendorong wirausaha untuk terus berjuang mencari peluang sampai memperoleh hasil. Kemauan dan kemampuan untuk mengambil risiko merupakan salah satu nilai utama dalam kewirausahaan. Wirausaha yang tidak mau mengambil risiko akan sukar memulai atau berinisiatif.

Hal yang hampir sama juga dikemukakan oleh informan 10:

"Salah satu yang membedakan antara seseorang biasa dan wirausaha adalah berani mengambil rsiko karena dalam dunia usaha terdapat ketidakpastian"

Hal tersebut semakin menjelaskan bahwa salah satu karakteristik yang harus dimiliki oleh seorang wirausaha adalah berani mengambil resiko. Salah satunya adalah resiko kegagalan atau kerugian.

"Hal yang tidak kalah penting adalah bagaimana seorang wirausaha bisa mengatasi permasalahan yang sedang dialami" kata informan 11.

Permasalahan dalam berwirausaha bisa datang dari berbagai hal misalnya masalah keuangan, masalah persaingan dunia usaha dan sebagainya. Apabila 
seorang wirausaha tidak bisa mengatasi permasalahan tersebut dengan segera maka kelangsungan usahanya pun juga akan terancam.

Karakter lain yang harus dimiliki oleh seorang wirausaha yang tidak kalah penting adalah memiliki visi yang jelas. Hal ini seperti apa yang dikemukakan oleh informan 12:

"Seorang wirausaha yang baik harus visioner atau beorientasi pada masa depan"

Seseorang wirausaha harus mempunyai visi ke. Sebuah usaha bukan didirikan hanya untuk sementara, tetapi untuk selamanya. Oleh sebab itu, seorang wirausaha akan menyusun perencanaan (planning) dan strategi yang matang agar jelas langkah-langkah yang akan dilaksanakan.

Sementara itu informan 13 mengatakan bahwa "hal yang juga harus dimiliki oleh seorang wirausaha adalah kejujuran, tekun dan disiplin". Untuk menjadi seorang wirausaha juga dibutuhkan sikap jujur, tekun. Jujur pada diri sendiri maupun seluruh karyawannya, tekun dalam mencari ide-ide baru yang lebih kreatif dari ide-ide yang sudah ada dan tekun dalam merintis usahanya yang baru akan mulai berkembang dan disiplin. Berdasarkan pernyataan yang telah dikemukakan oleh beberapa informan di atas dapat diketahui bahwa paradigma mahasiswa mengenai karakteristik seorang wirausaha adalah seorang wirausaha yang ingin berhasil harus memiliki karakteristik yang baik seperti: pantang menyerah jika terjadi kegagalan, kepemimpinan yang baik, berani mengambil resiko, bisa mengatasi permasalahan yang dihadapi dengan cepat atau responsif terhadap perubahan, visioner atau berorientasi pada masa depan, jujur tekun dan disiplin. Semua karakteristik itu sangat menunjuang keberhasilan seorang wirausaha.

\section{Inovasi wirausaha}

Inovasi adalah kemampuan untuk menerapkan kreativitas dalam rangka pemecahan masalah dan menemukan peluang (doing new thing). Inovasi memiliki fungsi yang khas bagi wirausahawan. Dengan inovasi wirausahawan menciptakan baik sumberdaya produksi baru maupun pengelolahan sumber daya yang ada dengan peningkatan nilai potensi untuk menciptakan sesuatu yang tidak ada menjadi ada. Mahasiswa program studi manajemen selaku informan 1 memberikan pendapatnya:

"Seorang wirausahawan harus selalu memberikan inovasi pada usaha yang dilakukannya".

Kewirausahaan adalah suatu proses menciptakan sebuah bidang usaha yang dijalankan oleh seseorang untuk memanfaatkan peluang dengan modal dan kesiapan dalam menghadapi risiko. Peluang tersebut dapat dimanfaatkan secara maksimal melalui sebuah inovasi atau penciptaan produk baru yang 
belum ada sehingga peluang tersebut dapat dimanfaatkan dengan efektif. Salah satu contoh inovasi yang dilakukan oleh wirausahawan mahasiswa program studi manajemen adalah custom casing handphone, dimana pembeli bisa menentukan desain casing handphone mereka sendiri sesuai dengan keinginan.

Hal serupa juga dikemukakan oleh informan 2 berkaitan dengan inovasi dalam wirausaha:

"Inovasi diperlukan untuk keberlangsungan sebuah usaha, kita harus terus berinovasi agar usaha tetap bertahan"

Kewirausahaan yang inovatif dimana seoarang wirausaha mampu melakukan proses untuk menghasilkan sesuatu yang baru. Inovasi tersebut haruslah merupakan sesuatu revolusioner, serta mampu memberikan persaingan dalam dunia usaha.

Menurut salah seorang informan 3 yang lain juga didapatkan hal yang sama. Usaha yang dilakukan bergerak dibidang clothing:

"Dalam sebuah usaha harus selalu berinovasi agar bisa bersaing dengan lainnya, misalnya dari segi desain dan lainnya”.

Hal tersebut menandakan bahwa dalam sebuah usaha inovasi merupakan hal yang sangat dibutuhkan, karena tuntutan dari perkembangan teknologi dan persaiangan. Apabila seorang wirausaha tidak berinovasi maka akan tertinggal.

Berkaitan dengan inovasi, informan 4 juga mengemukakan pendapatnya: "Salah satu cara untuk meningkatkan kualitas dalam usaha adalah berinovasi, baik inovasi produknya, inovasi pelayanannya dan yang lainnya"

Berdasarkan pendapat tersebut diketahui bahwa kemampuan berpikir yang kreatif dan inovatif dalam menciptakan sesuatu yang bernilai perlu dimiliki oleh seoarang wirausaha. Kemampuan berwirausaha yang kreatif dan inovatif dapat dijadikan dasar, kiat, dan sumberdaya untuk mencari peluang menuju sukses.

Hal senada diungkapkan oleh informan 5:

"Inovasi merupakan hal yang sangat penting, apalagi dalam sebuah usaha atau bagi wirausaha. Tanpa inovasi keberlangsungan usaha akan ternacam"

"Sangat penting. Inovasi dalam sebuah usaha sangat penting. Tanpa inovasi sebuah usaha tidak akan bisa berkembang" ujar informan 6 .

Peran inovasi dan kreativitas sangat penting dilakukan sebagai upaya dalam pengembangan produk dan pelayanan jasa dalam suatu usaha bisnis. Seoarang Kesuksesan dalam wirausaha tidak lain karena adanya kreativitas yang dilakukan dalam mengembangkan produk. Daya saing yang tinggi dalam berwirausaha tentunya akan mendorong wirausaha 
untuk lebih memiliki kreativitas yang lebih tinggi.

"Inovasi bisa dilakukan dengan berbagai cara misalnya kita meminta masukan kepada pelanggan setelah menggunakan produk kita, sehingga kita bisa melakukan perbaikan atau perubahan ke arah yang lebih baik". Hal ini dikatakan oleh informan 7.

Sedangkan informan 8 mengatakan "inovasi bisa dilakukan dengan berbagai cara misalnya sikap responsif terhadap perubahanperubahan yang ada misalnya perubahan kondisi pasar atau persaingan, dan hal itu sangat penting".

Sama halnya dengan apa yang dikatakan oleh informan 9 bahwa "menurut saya inovasi merupakan syarat utama dari kelangsungan usaha seseorang"

Seoarang wirausaha perlu memiliki sikap inovatif dalam berwirausaha. Sikap ini merupakan syarat utama agar mampu menyesuaikan diri dengan situasi dan kondisi usaha yang selalu berubah. Inovasi dapat memberikan perubahan dalam berwirausaha baik dalam materil maupun nonmateril. Keberlangsungan suatu usaha sangat dipengaruhi oleh inovasi yang dilakukan.

"Sikap inovatif memang harus dimiliki apabila kita ingin terjun dalam dunia usaha, kalau tidak ya ketinggalan" kata informan 10.

Hal yang hampir sama juga diungkapkan oleh informan 11 bahwa "inovatif dan kreatif sangat diperlukan dalam usaha apapun". Inovasi merupakan hal penting jika ingin usahanya bertahan dan semakin berkembang. Untuk melakukan inovasi tentu diperlukan ide kreatif. Ide - ide kreatif inilah yang bisa menjadi pembeda antara usaha yang satu dengan usaha yang lain.

Sikap inovatif sangat diperlukan untuk menghadapi persaingan usaha. Sama seperti yang dikemukakan oleh informan 12:

"Inovatif dan kreatif itu sangat penting, kalau tidak berinovasi ya pasti kalah bersaing dengan kompetitornya"

"Inovasi dilakukan dengan menciptakan sesuatu yang baru dan itu sangat diperlukan dalam sebuah usaha". Hal ini dikatakan informan 13.

Berdasarkan pernyataan yang telah diungkapkan oleh informan di atas diketahui bahwa paradigma mahasiswa mengenai inovasi yaitu inovasi merupakan hal yang sangat penting dalam sebuah usaha. Tanpa adanya inovasi sebuah usaha tidak akan mampu menghadapai tantangan yang ada. Inovasi dapat dilakukan dengan cara meminta kritik dan saran untuk pengambangan produk dan kualitas layanan. Selain itu, responsif terhadap perubahan-perubahan yang terjadi di pasar serta strategi untuk menghadapi perubahan tersebut.

\section{Modal Wirausaha}

Modal adalah dana yang digunakan untuk membiayai kegiatan 
operasional kewirausahaan. Modal dapat berasal dari diri sendiri maupun pinjaman. Sumber pendanaan memilliki tingkat resiko yang berbeda-beda. Seoarang wirausaha harus mampu memperhitungkan tingkat resiko agar tidak menghambat usaha kedepannya. Seoarang wirausaha yang mandiri dalam pendanaan usaha memiliki tingkat resiko yang rendah.

"Modal merupakan langkah awal untuk memulai sebuah usaha". Hal ini yang dikatakan oleh informan 1 .

Sama halnya dengan apa yang telah dikemukakan oleh informan 2: "penting banget, gimana mau memulai usaha kalau tidak ada modal uangnya"

Modal merupakan kunci dari sebuah usaha. Tanpa adanya modal sebuah usaha tidak dapat dijalankan. Modal menjadi salah satu bagian yang penting dalam memulai, menjalankan dan mengembangkan usaha. Besarnya modal yang dimiliki, mempengaruhi besar kecilnya usaha yang akan dibangun.

Pendapat yang lain dikemukakan oleh informan 3 terkait dengan modal:

"Modal berkaitan dengan keuangan. Seorang wirausaha harus pintar mengelola keuangan untuk kelangsungan usahnya"

"Kalau menurut saya, besar kecilnya modal akan mempengaruhi kelancaran sebuah usaha" Hal ini dikemukakan oleh informan 4.
Modal sangat berkaitan dengan keuangan sebuah usaha. Apabila keuangan suatu usaha 'sehat' maka kelangsungan usaha tersebut akan berlangsung lama, begitu juga sebaliknya. Sumber pendanaan memilliki tingkat resiko yang berbeda-beda. Seoarang wirausaha harus mampu memperhitungkan tingkat resiko agar tidak menghambat usaha kedepannya. Seoarang wirausaha yang mandiri dalam pendanaan usaha memiliki tingkat resiko yang rendah. Hal ini karena jika usaha yang dilakukan tidak mendapatkan laba atau rugi, seoarang wirauasaha akan merugi sebatas pada modalnya yang berkurang.

"Kunci dari awal sebuah usaha ada pada modal yang dimiliki" hal ini dikatakan oleh informan 5.

Sama seperti apa yang dikatakan oleh informan 6 bahwa: "Harus punya modal dulu, baru usahanya bisa dimulai:

Berdasarkan pendapat dari informan tersebut diketahui bahwa modal merupakan hal pertama yang harus dimiliki oleh seseorang yang ingin memulai usahanya. Tanpa adanya modal sebuah usaha tidak bisa dimulai.

Sementara itu pendapat yang berbeda dikatakan oleh informan 7 bahwa sebuah usaha tidak harus diawali dengan sebuah modal yang besar:

"Saya memulai sebuah usaha awalnya ikut dengan teman tapi sekarang saya menjalankannya 
sendiri, usaha saya seperti reseller jadi tidak memerlukan modal".

"Modal dalam berwirausaha merupakan hal yang sangat penting. Tetapi tidak semua usaha harus dimulai dengan modal yang besar" kata informan 8 .

Berdasarkan hasil wawancara tersebut dapat diketahui bahwa tidak semua usaha membutuhkan modal awal yang besar, bahkan terdapat usaha yang tidak memerlukan modal seperti reseller.

Sama halnya dengan apa yang dikatakan oleh informan 9 bahwa usaha tidak harus diawali dengan modal yang besar:

"Saya memulai usaha tidak dengan modal tetapi joint dengan teman. Jadi teman saya yang menyediakan modal berupa barang kemudian saya bagian penjualannya. Saya hanya menjual tidak mengeluarkan modal berupa uang"

Dalam mendirikan suatu usaha, dapat membentuk suatu usaha sesuai dengan modal yang dimiliki. Kebutuhan akan modal berdampak pada pemilihan bentuk usaha yang akan dijalankan. Bentuk usaha dapat dilakuakan dengan mendirikan perusahaan milik sendiri (sole proprietorship), persekutuan (partnership), dan kerja sama manajemen (franchising). Hal ini dapat disesuaikan dengan perencanaan awal dalam mendirikan suatu usaha yang disesuaikan dengan tujuan dalam berwirausaha.
Modal merupakan hal yang penting dalam wirausaha. Informan 10 mengungkapkan pendapatnya: "Modal merupakan hal yang penting dalam wirausaha, tetapi modal disini bisa juga beupa ide, ide kreatif", "Menurut saya ide juga merupakan salah satu modal, dan itu tidak kalah penting dari modal yang berupa uang, sebab kalau kita punya uang tetapi tidak punya ide mau buat usaha apa ya percuma saja" kata informan 11.

Modal utama wirausaha adalah kreativitas, keuletan, semangat pantang menyerah. Kreativitas ini akan memberikan bekal untuk seorang wirausaha untuk berpikir dan bertindak kreatif.

Hal yang hampir sama juga dikemukakan oleh informan 12 tentang modal berwirausaha:

"Menurut saya modal (uang) dalam berwirausaha memang sangat penting tetapi modal yang lain pun juga tidak kalah penting, misalnya modal berupa ide - ide kreatif dan inovatif"

"Baik modal uang atau modal ide kreatif sangat diperlukan dalam sebuah usaha, keduanya saling melengkapi". Hal ini dikemukakan oleh informan 13.

Jika selama ini sebagian orang hanya berfokus pada modal material untuk mendirikan sebuah bisnis, ide yang juga dikenal sebagai modal intelektual ternyata sangat penting untuk dimiliki oleh para wirausahawan. Tanpa ide unik dan 
kreatif, modal usaha berupa materi tidak dapat dikembangkan menjadi sebuah bisnis kreatif. Namun sebaliknya, jika ide sudah dimiliki sebelum memiliki modal material, ide tersebut kemudian dapat menjadi magnet tersendiri untuk menarik investor dalam membantu mengembangkan bisnis. Oleh karena itu, ide merupakan modal intelektual yang dapat membentuk modal usaha lainnya.

Berdasarkan beberapa pendapat yang telah dikemukakan oleh informan di atas diketahui bahwa paradigma mahasiswa terkait dengan modal yaitu modal merupakan sesuatu yang sangat penting untuk memulai sebuah usaha. Selain modal berupa uang, hal yang tidak kalah penting adalah modal berupa ide kreatif.

\section{Pembahasan Penelitian}

\section{Paradigma mahasiswa tentang karakteristik kewirausahaan}

Hasil analisis paradigma mahasiswa terhadap kewirausahaan menunjukkan bahwa karakteristik kewirausahaan menurut informan di antaranya pantang menyerah dalam menjalankan usaha. Seorang wirausaha dalam menjalankan usaha tentunya pernah mengalami kegagalan. Sifat pantang menyerah, semangat dalam menjalankan aktivitas usaha penting dimiliki seoarang wirausaha. Hal ini sesuai dengan pendapat Lubis (2011) yang menyatakan bahwa "seoarang wirausaha memiliki karakteristik diataranya kretif, memiliki impian masa depan, berpikiran bebas, pekerja keras, optimis, inovator, berani mengambil resiko, dan memiliki jiwa kepemimpinan".

Karakteristik lainnya yang diungkapkan oleh informan yaitu seorang wirausaha harus mampu mengatasi permasalahan yang dihadapi selama menjalankan usaha yang dijalankan. Hambatan atau permasalahan baik yang berasal dari internal maupun eksternal., seoarang wirausaha harus mampu melewati dan menyelesaikannya. Upaya tersebut dilakukan agar usaha yang dilakukan dapat berjalan sesuai dengan tujuan yang diharapkan. Menurut Rye dalam saiman (2015) mengungkapkan bahwa seoarang wirausaha yang sukses mempunyai beberapa karakteristik diantaranya "pengendalian diri, mengusahakan terselesaikannya urusan, mengarahkan diri sendiri, mengelola dengan sasaran, penganalisis kesempatan, pengendali pribadi, pemikir kreatif, pemecah masalah, dan pemikir objektif'. Oleh karena itu, seoarang wirausaha harus mampu menjadi seoarang yang dapat memecahkan permasalahan selam melaksanakan usaha.

Seorang wirausaha dalam melaksanakan usaha memiliki visi kedepan untuk menuju kesuksesan dalam berwirausaha. Seperti yang diungkapkan oleh informan bahwa seorang wirausaha memiliki berorientasi pada masa depan agar 
lebih baik dari sebelumnya. Perubahan kondisi ekonomi seprti yang dijelaskan bahwa memiliki kemakmuran lebih baik dari pada kondisi sebelum berwirausaha. Orientasi kedepan merupakan karakteristik yang perlu dimiliki oleh seorang wirausaha. Orientasi kedepan untuk memacu motivasi seoarang wirausaha untuk sukses dalam menjalankan usaha. Seperti yang dijelaskan oleh Suryana (2017) yang menjelaskan bahwa indikator yang dimiliki seorang wirausaha dianatanya memiliki "sifat percaya diri, berorientasi pada hasil, berani mengambil resiko, kepemimpinan, keorisinalitasan, dan berorientasi pada masa depan".

\section{Paradigma mahasiswa tentang} inovasi dalam wirausaha

Paradigma mahasiswa

berkaitan dengan inovasi dalam kegiatan wirausaha merupakan aktivitas pembaharuan dalam kegiatan usaha. Seperti yang dikatakan oleh informan salah satunya pembaharuan pada produk yang dihasilkan. Seoarang wirausaha harus menjadi seoarang yang inovator dalam melaksanakan usaha. Hal ini sesuai dengan pendapat Lubis (2011) yang menayatakan bahwa seoarang wirausaha memiliki karakteristik inovator yang berkaitan dengan usaha yang dijalankan.

Berbagai upaya yang dilakukan untuk mengambangkan suatu usaha di antaranya dengan meminta saran dan masukan yang berkaitan dengan kelebihan dan kekurangan produk atau pelayanan usaha. Paradigmana mahasiswa tersebut sesuai dengan yag dikatakan oleh Gedik at al (2015) yang mengatakan bahwa seoarang wirausaha harus terhubung dengan karyawan atau pelanggan untuk mendapatkan informasi dalam meningkatkan proses pelayanan dan produk yang dihasilkan.

Persaingan dalam usaha merupakan hal yang wajar dalam dunia usaha. Berkaitan dengan daur sklus hidup produk juga menekankan bahwa dalam setiap tahap produk ada masa diamana pesaing akan memasuki dunia usaha yang digeluti. Oleh karena itu, seorang wirausaha harus mampu untuk mempersiapkan diri untuk merespon persaingan usaha tersebut. Hal ini seperti yang ungkapkan oleh Gedik at al (2015) bahwa seoarang wirausaha harus memiliki rencana strategis yang responsif terhadap perubahan selama menjalankan kegiatan usaha.

\section{Paradigma mahasiswa tentang modal dalam berwirausaha}

Keuangan atau permodalan penting dimiliki oleh seoarang wirausaha untuk menjalankan proses produksi dan pelayanan dalam usaha. Sumber keuangan dalam berwirausaha dapat berasal dari sumber internal dan eksterna. Hal ini sesuai dengan pendapat Suryana (2017) bahwa "terdapat sumber utama pendanaan dalam usaha yaitu 
ekuitas dan utang”. Ekuitas atau modal usaha merupakan modal yang bersumber dari pemilik atau internal seorang wirausaha.

Modal usaha yang dimiliki seoarang wirausaha harus memiliki sifat kemandirian. Salah satu modal modal usaha yang dimiliki oleh seoarang wirausaha adalah uang. Modal usaha dalam bentuk uang merupakan salah satu sumber daya eksternal yang dimiliki oleh seoarang wirausaha. Hal ini sesuai dengan pendapat Ikhsan (2010) yang menyatakan bahwa salah satu jenis modal utama seoarang wirausaha selain sumber daya internal yaitu sumber daya eksternal yaitu uang yang cukup untuk membiayai modal usaha dan modal kerja, dan jaringan sosial.

$\begin{array}{rrr}\text { Ide } & \text { kreatifitas } & \text { seoarang } \\ \text { wirausaha } & \text { merupakan } & \text { sebuah }\end{array}$ pemikiran yang penting dimiliki oleh seoarang wirausaha. Seoarang wirausaha harus memiliki ide dalam memanfaatkan peluang atau kesempatan agar mampu menghasilkan pelayanan dan produk yang terbaik sesuai dengan kebutuhan masyarakat. Kepemilikan ide kreatif dengan kesempatan akan memberikan modal tersendiri untuk seoarang wirausaha. Hal ini sesuai dengan pendapat ikhsan (2010) yang menyatakan bahwa kesempatan merupakan salah satu sumber daya modal berupa faktor $\mathrm{X}$ yang dimiliki oleh seoarang wirausaha.

\section{KESIMPULAN}

1. Mahasiswa Program Studi Manajemen Universitas Pamulang (UNPAM) tahun ajaran 2017/2018 terdiri dari berbagai latar belakang karakter, sosial dan daerah yang berbeda-beda. Secara umum segmen pasar mahasiswa Unpam adalah masyarakat menengah ke bawah. Mahasiswa program studi manajemen yang merupakan wirausahawan yaitu reguler A sejumlah 19 mahasiswa, reguler B sejumlah 34 mahasiswa, dan reguler $\mathrm{C}$ sejumlah 55 mahasiswa Jumlah tersebut merupakan potensi yang besar untuk menghasilkan mahasiswa yang memiliki kemampuan berpikir ekonomi kreatif melalui kewirausahaan. Bidang usaha yang dilakukan oleh mahasiswa diantaranya tergolong dalam usaha kuliner sebanyak 21 mahasiswa, bidang jasa sebanyak 34 mahasiswa, dan bidang usaha perdagangan sebanyak 53 mahasiswa. Sumber permodalan mahasiswa mayoritas berasal dari sumber mandiri yaitu sebanyak 94 mahasiswa dan sebagiannya memperoleh modal dari pinjaman. Lama usaha yang dilakukan oleh mahasiswa mulai rentang 0 sampai dengan 5 tahun.

2. Paradigma mahasiswa tentang kewirausahaan yaitu kegiatan yang dilakukan oleh seseorang untuk menciptakan dan melaksanakan usaha. Seorang 
wirausaha memiliki karakteristik, inovasi dalam wirausaha dan memiliki modal usaha. Paradigma mahasiswa mengenai karakteristik wirausaha seperti pantang menyerah jika terjadi kegagalan, kepemimpinan yang baik, berani mengambil resiko, bisa mengatasi permasalahan yang dihadapi dengan cepat atau responsif terhadap perubahan, berorientasi pada masa depan, jujur, tekun, dan disiplin. Paradigma mahasiswa tentang inovasi yaitu peningkatan layanan dan pembaharuan produk, antisipasi perubahan. Inovasi merupakan hal yang sangat penting dalam sebuah usaha. Pembaharuan akan strategi, produk dan layanan akan membantu seorang wirausaha dalam mempertahankan usaha yang dijalankan. Paradigma mahasiswa terkait dengan modal yaitu berupa uang yang digunakan untuk menjalankan aktivitas usaha. Modal merupakan sesuatu yang sangat penting untuk memulai sebuah usaha. Selain modal berupa uang, hal yang tidak kalah penting adalah modal berupa ide kreatif.

\section{REFERENSI}

Ahimsa-Putra, H.S. (2008). Paradigma dan Revolusi Ilmu Dalam Antropologi Budaya: Sketsa Beberapa Episode. Pidato Pengukuhan Guru Besar.
Yogyakarta; Universitas Gadjah Mada.

Alma, Buchari. (2010). Kewirausahaan. Bandung : Alfabeta.

Capra, F. (1991). Tao of Physics. London: Flamingo.

Gedik, S., Miman, M., Kesici, Mehmet S. (2015). Characteristics and Attitudes of Entrepreneurs Towards Entrepreneurship. Doi: 10.1016/j.sbspro.2015.06.153.

Kasmir. (2006). Kewirausahaan. Jakarta: Rajawali Pers.

Kristanto, Heru. (2009).

Kewirausahaan

(Entrepreneurship): Pendekatan Manajemen dan Praktik. Yogyakarta: Graha Ilmu.

Lubis, Hari. (2011). Kewirausahaan. Jakarta : Universitas Terbuka.

Moleoang, Lexy J. (2011). Metodologi Penelitian kualitatif. Bandung: PT Remaja Rosdaharya.

Mouritsen, J., Bukh, P.N., Larsen, H.T. and Johansen, M.R. (2002). Developing and managing knowledge through intellectual capital statements. Journal of Intellectual Capital, Vol. 3 No. 1, pp. 10-29.

Skaikh, J.M. (2004). Measuring and Reporting of Intellectual Capital Performance Analysis. The Journal of American Academy of Business, March: pp.439-448. 
Stokes, D. and Wilson, N. (2006).

Small Business Management and

Entrepreneurship, 5th ed.,

Thomson, London.

Sukirno, Sadono. (2009). Mikro

Ekonomi Teori Pengantar, Edisi

Ketiga. Jakarta: Raja Grafindo

Persada.

Suryana. (2017). Kewirausahaan:

kiat dan proses menuju sukses

edisi keempat. Jakarta: Salemba Empat.

Utami, Setyaningsih Sri Dan Edi Wibowo. (2013). Pengaruh

Modal Kerja Terhadap

Pendapatan Dengan Lama Usaha

Sebagai Variabel Moderasi

(Survei Pada Pedagang Pasar Klithikan Notoharjo Surakarta).

Jurnal Ekonomi Dan

Kewirausahaan Vol. 13, No. 2,

Oktober 2013: Hal. 171180. 